Supporting Information for

\title{
A sulfido-bridged diiron(II) compound and its reactions with nitrogenase-relevant substrates
}

\author{
Javier Vela, Sebastian Stoian, Christine Flaschenriem, Eckard Münck,* \\ and Patrick L. Holland*
}

Synthesis, characterization, and experimental procedures $\quad$ S-2

Figure S.1. ${ }^{1} \mathrm{H}$ NMR spectrum of $1 \quad$ S-4

Scheme S.1. Binding of $\mathrm{CH}_{3} \mathrm{CN}$ to 1

Figure S.2. X-ray crystal structures of $\mathbf{1} \cdot \mathbf{2} \mathbf{H}_{2} \mathbf{N N H M e}$ and $\mathbf{1} \cdot \mathbf{2} \mathbf{N H}_{\mathbf{3}} \quad \mathrm{S}-7$

Figure S.3. Titration of phenylhydrazine and 1

Figure S.4. Visible spectra of mixtures of 1 and $2 \quad$ S-9

Table S.1 Recovery of ammonia during formation of $2 \quad$ S-10

$\begin{array}{ll}\text { Details on Spectroscopy } & \text { S-11 }\end{array}$

$\begin{array}{lr}\text { Figure S.5. Mössbauer spectra of } 1 & \text { S-12 }\end{array}$

Table S.2. Selected data for crystal structures of 1

$\begin{array}{ll}\text { Figure S.6. Crystal structures of } 1 & \text { S-14 }\end{array}$

Tables S.3, S.4. Tabulation of literature pyramidalizations $\quad$ S-15

$\begin{array}{ll}\text { References } & \text { S-18 }\end{array}$ 


\section{General considerations}

Manipulations were performed under a nitrogen atmosphere by standard Schlenk techniques or in an M. Braun Unilab $\mathrm{N}_{2}$-filled glove box maintained at or below $1 \mathrm{ppm}$ of $\mathrm{O}_{2}$ and $\mathrm{H}_{2} \mathrm{O}$. Glassware was dried at $150{ }^{\circ} \mathrm{C}$ overnight. Proton NMR data were recorded on a Bruker Avance $400 \mathrm{MHz}$ spectrometer at room temperature $\left(21^{\circ} \mathrm{C}\right)$. Shifts ( $\square$ are reported in ppm, relative to residual protiated solvent in $\mathrm{C}_{6} \mathrm{D}_{6}(7.15 \mathrm{ppm})$. In parentheses are listed $T_{2}$ values in ms (calculated as $\left.\left(\square \square \square_{1 / 2}\right)^{-1}\right),{ }^{1}$ integrations, and assignments. In some cases, overlapping of peaks prevented $T_{2}$ determinations. Solution magnetic susceptibilities were determined at $294 \mathrm{~K}$ by the Evans method. ${ }^{2}$ Celite was dried at 200 ${ }^{\circ} \mathrm{C}$ under vacuum overnight. Microanalyses were performed by Desert Analytics (Tucson, AZ). Infrared data were obtained in a Shimadzu FT-IR 8400S spectrometer. Aniline detection was carried out with an HP5890 GC-MS equipped with an RTX-5 column (15 $\mathrm{m}, 0.25 \mathrm{~mm} \mathrm{ID})$; helium (600 $\mathrm{kPa})$ was used as the carrier gas. Ammonia was determined by the indophenol method (see below). ${ }^{3}$ Pentane, diethyl ether, tetrahydrofuran (THF) and acetonitrile were purified by passage through activated alumina and "deoxygenizer" columns from Glass Contour Co. (Laguna Beach, CA). Deuterated benzene was dried over $\mathrm{CaH}_{2}$, then over $\mathrm{Na}$, and then vacuum distilled into a storage container or directly into the NMR tube. Sulfur and phenylhydrazine were crystallized at $-40{ }^{\circ} \mathrm{C}$ prior to use (from toluene and diethyl ether, respectively). Anhydrous ammonia was supplied by Matheson. $\mathrm{L}^{\mathrm{Me}} \mathrm{FeCl}_{2} \mathrm{Li}(\mathrm{THF})_{2}$ was made by the reported procedure. ${ }^{4}$

Synthesis of $\left[\boldsymbol{L}^{\text {Me }} \mathbf{F e N}\right]_{2}$. A slurry of $\mathrm{L}^{\mathrm{Me}} \mathrm{FeCl}_{2} \mathrm{Li}(\mathrm{THF})_{2}(6.55 \mathrm{~g}, 9.4 \mathrm{mmol})$ in toluene (20 mL) was stirred and heated to $80{ }^{\circ} \mathrm{C}$ overnight. After cooling to room temperature, the solvent was completely pumped down under vacuum. Pentane $(20 \mathrm{~mL})$ and $\mathrm{KC}_{8}(1.5$ 
$\mathrm{g}, 11.3 \mathrm{mmol}, 1.2$ equiv) were added and the suspension was stirred at room temperature overnight. The resulting mixture was allowed to settle for 2 hours and the solution phase was decanted and filtered through a frit. Concentration to $10 \mathrm{~mL}$ and cooling $\left(-38^{\circ} \mathrm{C}\right)$ afforded crystals (6.3 g in 9 crops, $6.5 \mathrm{mmol}, 68 \%$ yield). Note: This compound is unstable in the presence of benzene. ${ }^{5}{ }^{1} \mathrm{H}$ NMR $\left(\mathrm{C}_{6} \mathrm{H}_{12}\right): \square 60\left(0.9,6 \mathrm{H}, \square-\mathrm{CH}_{3}\right),-15(3$, $\left.12 \mathrm{H},{ }^{i} \mathrm{PrCH}_{3}\right),-17(6,4 \mathrm{H}, m-\mathrm{CH}),-91(4,2 \mathrm{H}, p-\mathrm{CH}),-102\left(1,12 \mathrm{H},{ }^{\mathrm{i}} \mathrm{PrCH}_{3}\right),-120(0.2$, $\left.4 \mathrm{H},{ }^{i} \mathrm{PrCH}\right) ; \square_{\text {eff }}($ Evans $)=8.2(4) \square_{\mathrm{B}}$; Vis (pentane): $499 \mathrm{~nm}\left(6560 \mathrm{M}^{-1} \mathrm{~cm}^{-1}\right)$. Anal. Calcd for $\mathrm{C}_{58} \mathrm{H}_{82} \mathrm{~N}_{6} \mathrm{Fe}_{2}$ : C, 71.45, H, 8.48, N, 8.62. Found: C, 71.24, H, 8.14, N, 8.51.

Synthesis of $\left(\boldsymbol{L}^{M e} \mathrm{Fe}\right)_{2}(\square-S)(1)$. A solution of sulfur $(18.7 \mathrm{mg}, 583 \square \mathrm{mol})$ in tetrahydrofuran $(2 \mathrm{~mL})$ was added dropwise to a stirring solution of $\left[\mathrm{L}^{\mathrm{Me}} \mathrm{FeN}\right]_{2}(600 \mathrm{mg}$, $615 \square \mathrm{mol}, 1.05$ equiv) in diethyl ether ( $3 \mathrm{~mL})$ at room temperature. After two hours the solution was filtered through Celite and concentrated under vacuum. Crystals were obtained from pentane $(5 \mathrm{~mL})$ at $-38{ }^{\circ} \mathrm{C}\left(468 \mathrm{mg}\right.$ in two crops, $82 \%$ yield). ${ }^{1} \mathrm{H}$ NMR (shown in Figure S.1) $\left(\mathrm{C}_{6} \mathrm{D}_{6}\right)$ : $\square 25.9(9,1 \mathrm{H}, \square-\mathrm{CH}), 20.8\left(18,6 \mathrm{H}, \square-\mathrm{CH}_{3}\right), 4.7(19,4 \mathrm{H}$, $m$-CH), $-2.1\left(27,12 \mathrm{H},{ }^{\mathrm{i}} \mathrm{PrCH}_{3}\right),-10.4(16,2 \mathrm{H}, p-\mathrm{CH}),-12.7\left(4,4 \mathrm{H},{ }^{\mathrm{i}} \mathrm{PrCH}\right),-21.5(9,12 \mathrm{H}$, $\left.{ }^{\mathrm{i}} \mathrm{PrCH}_{3}\right) ; \square_{\text {eff }}($ Evans $)=4.2(3) \square_{\mathrm{B}}$; Vis (toluene): $516 \mathrm{~nm}\left(2630 \mathrm{M}^{-1} \mathrm{~cm}^{-1}\right)$. Anal. Calcd for $\mathrm{C}_{58} \mathrm{H}_{82} \mathrm{~N}_{4} \mathrm{SFe}_{2}: \mathrm{C}, 71.15, \mathrm{H}, 8.44, \mathrm{~N}$, 5.72. Found: C, 70.67, H, 8.45, N, 6.24. 


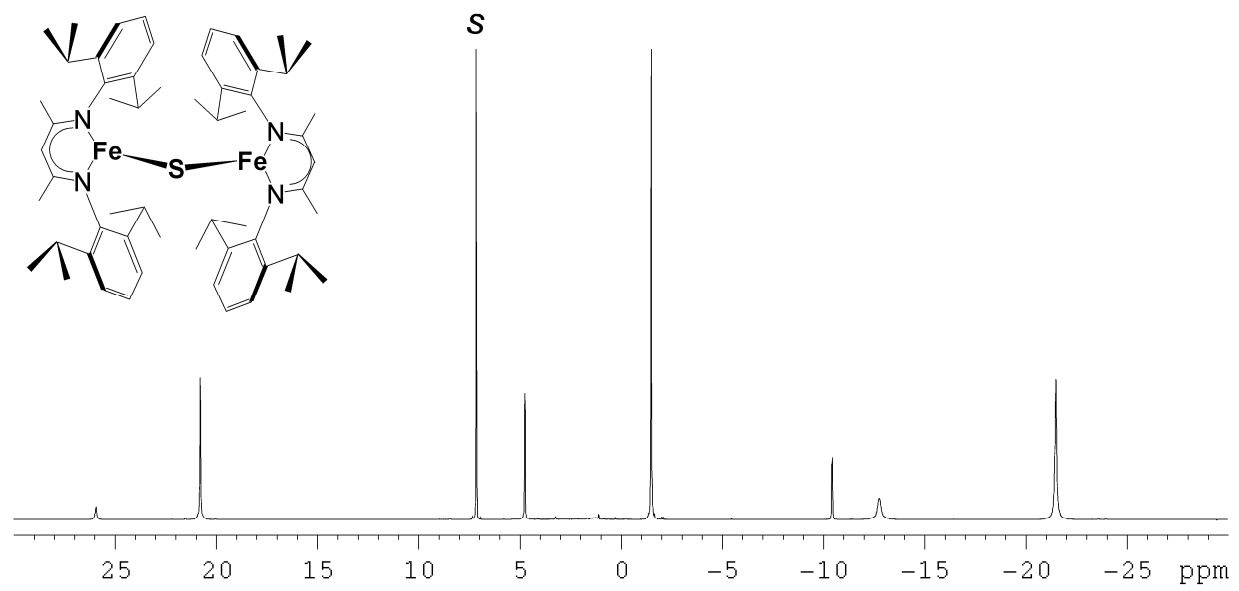

Figure S.1. ${ }^{1} \mathrm{H}$ NMR spectrum $\left(\mathrm{C}_{6} \mathrm{D}_{6}, \mathrm{RT}\right)$ of $\mathbf{1}$. Peak assignments are listed above, and the solvent resonance is marked with $S$.

Interaction of 1 with nitrogen donors. Titration of 1 with $\mathrm{CH}_{3} \mathrm{CN}$ (Scheme S.1): To a solution of $1(25 \mathrm{mg})$ in benzene- $d_{6}\left(0.4 \mathrm{~mL},[\mathrm{FeSFe}]_{0}=64 \mathrm{mM},[\mathrm{Fe}]_{\mathrm{T}}=128 \mathrm{mM}\right)$ was added acetonitrile repeatedly in small aliquots (about $0.4 \square \mathrm{L}$ each) through a microsyringe. ${ }^{1} \mathrm{H}$ NMR spectra were recorded before the experiment and after every acetonitrile addition. The titration curve and Job plot show the stoichiometry of the main adduct to be 1:1 (see text). To obtain the equilibrium constant, the data was subjected to a least squares iterative procedure ${ }^{6}$ by fitting to the equation

$$
\mathrm{L}_{\mathrm{T}} / \square=\left(\mathrm{L}_{\mathrm{T}}+\mathrm{S}_{\mathrm{T}}-[\mathrm{SL}]\right) / \square_{11}+1 /\left(\square_{11}-\mathrm{K}_{\mathrm{eq}}\right) \text {, }
$$

where $\mathrm{L}_{\mathrm{T}}$ is the total added concentration of acetonitrile, $\mathrm{S}_{\mathrm{T}}$ and $[\mathrm{SL}$ ] are the total and $\mathrm{CH}_{3} \mathrm{CN}$-bound concentrations of sulfide, $\mathrm{S}_{\mathrm{T}}=[\mathbf{1}]+\left[\mathbf{1} \bullet \mathrm{CH}_{\mathbf{3}} \mathbf{C N}\right],[\mathrm{SL}]=\left[\mathbf{1} \bullet \mathbf{C H}_{\mathbf{3}} \mathbf{C N}\right]$. The value of $\square$ is the difference between the chemical shift observed and that of free sulfide, $\square=\square_{b s}-\square_{3}$; and $\square_{11}$ is the difference between the chemical shift of adduct $\mathbf{1} \cdot \mathbf{C H}_{\mathbf{3}} \mathbf{C N}$ and that of free 1, $\square=\square_{4}-\square_{3}$. Convergence was achieved after 4 cycles and the final value of the binding constant is $\mathrm{K}_{\mathrm{eq}}=340(60) \mathrm{M}^{-1}$. 

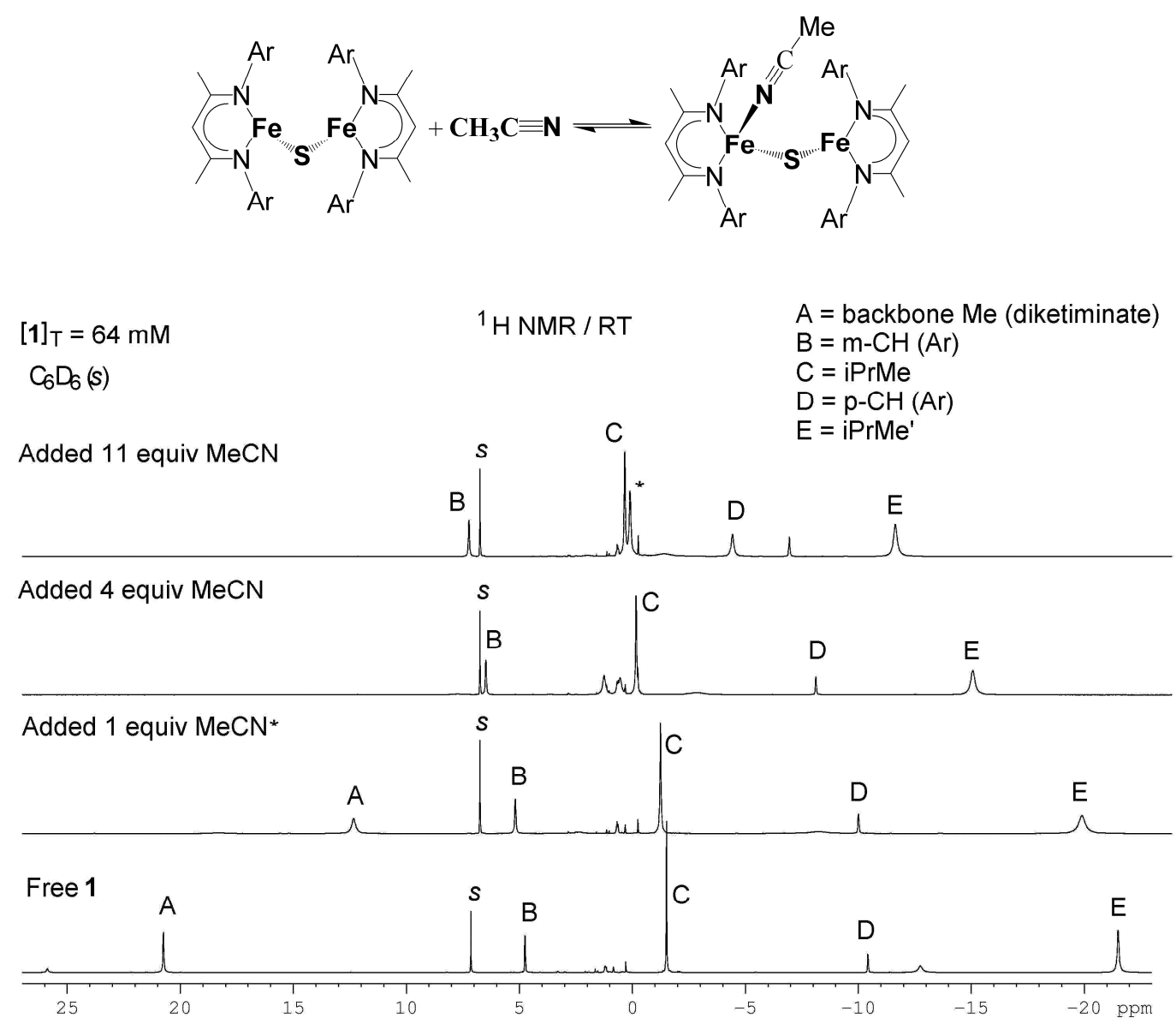

Scheme S.1. Variation of chemical shifts for 1 upon addition of acetonitrile due to fast exchange of free and bound species on the ${ }^{1} \mathrm{H}$ NMR time scale. Only some peak assignments and spectra are shown.

Isolation of adducts of 1. $\left[\left(\mathrm{L}^{\mathrm{Me}} \mathrm{Fe}\right)_{2}(\square-\mathrm{S})\left(\square^{1}-\mathrm{CH}_{3} \mathrm{CN}\right)\right]\left(\mathbf{1} \cdot \mathbf{C} \mathbf{H}_{3} \mathbf{C N}\right)$. Crystals were grown from a concentrated solution of $\mathbf{1}(100 \mathrm{mg}, 102 \square \mathrm{mol})$ and acetonitrile (100 $\square \mathrm{L}$, 1.94 mmol, 19.0 equiv) in diethyl ether at $-38{ }^{\circ} \mathrm{C}(74 \mathrm{mg}, 71 \%) .{ }^{1} \mathrm{H}$ NMR $\left(\mathrm{C}_{6} \mathrm{D}_{6}\right): \square 7.6$ (14, 4H, m-CH), $2.5(2,1 \mathrm{H}, \square-\mathrm{CH}), 0.9\left(13,12 \mathrm{H},{ }^{\mathrm{i}} \mathrm{PrCH}_{3}\right), 0.6\left(9,3 \mathrm{H}, \mathrm{N} \equiv \mathrm{CCH}_{3}\right),-0.9$ (0.8, 4H, $\left.{ }^{\mathrm{P} r C H}\right),-3.8\left(6,6 \mathrm{H}, \mathrm{\square}-\mathrm{CH}_{3}\right),-6.3(14,2 \mathrm{H}, p-\mathrm{CH}),-10.9\left(4,12 \mathrm{H},{ }^{\mathrm{i}} \mathrm{PrCH}_{3}\right)$; IR $(\mathrm{KBr}): 2303 \mathrm{~cm}^{-1}(\mathrm{~m}, \mathrm{C} \equiv \mathrm{N})$; $\square_{\text {eff }}($ Evans $)=5.1(3) \square_{\mathrm{B}}$; Vis (toluene-acetonitrile 1:1 v/v): 
$501 \mathrm{~nm}\left(3530 \mathrm{M}^{-1} \mathrm{~cm}^{-1}\right)$. Anal. Calcd for $\mathrm{C}_{60} \mathrm{H}_{85} \mathrm{~N}_{5} \mathrm{SFe}_{2}: \mathrm{C}, 70.64, \mathrm{H}, 8.40, \mathrm{~N}, 6.87$. Found: C, 71.00, H, 8.64, N, 6.89.

$\left[\mathbf{L}^{\mathrm{Me}} \mathbf{F e}\left(\square^{1}-\mathbf{M e}_{2} \mathbf{N N H}_{2}\right)_{2}(\square-\mathbf{S})\right]\left(\mathbf{1} \cdot \mathbf{2} \mathbf{H}_{2} \mathbf{N N M e}_{2}\right) .1,1$-Dimethylhydrazine (50 $\square \mathrm{L}$, excess) was added through a microsyringe to a stirring solution of $\mathbf{1}(142 \mathrm{mg}, 145 \square \mathrm{mol})$ in $5 \mathrm{~mL}$ of diethyl ether at room temperature. After ten minutes the solution was filtered through Celite and concentrated to $1 \mathrm{~mL}$ under vacuum. Cooling to $-38{ }^{\circ} \mathrm{C}$ afforded red crystals (136 mg, 86\% yield). ${ }^{1} \mathrm{H}$ NMR $\left(\mathrm{C}_{6} \mathrm{D}_{6}\right): \square 22.9(0.5,2 \mathrm{H}, p-\mathrm{CH}), 6.7(2,4 \mathrm{H}, m-\mathrm{CH}), 2.3$ (5, $\left.2 \mathrm{H}, \mathrm{NH}_{2}\right), 1.1\left(2,18 \mathrm{H},{ }^{\mathrm{i}} \mathrm{PrCH}_{3}\right.$ and $\left.\mathrm{NMe}_{2}\right),-2.4\left(0.2,6 \mathrm{H}, \mathrm{\square}-\mathrm{CH}_{3}\right),-7.2(1 \mathrm{H}, \mathrm{\square}-\mathrm{CH}),-7.6$ (3, 4H, $\left.{ }^{\mathrm{PrCH}}\right),-14.2\left(0.7,12 \mathrm{H},{ }^{\mathrm{i}} \mathrm{PrCH}_{3}\right)$; IR $(\mathrm{KBr}): 3240 \mathrm{~cm}^{-1}(\mathrm{w}, \mathrm{N}-\mathrm{H})$; $\square_{\text {eff }}($ Evans $)=$ 4.4(3) $\square_{B}$; Vis (toluene): $502 \mathrm{~nm}\left(2160 \mathrm{M}^{-1} \mathrm{~cm}^{-1}\right)$. Anal. Calcd for $\mathrm{C}_{62} \mathrm{H}_{98} \mathrm{~N}_{8} \mathrm{SFe}_{2}: \mathrm{C}, 67.75$, H, 8.99, N, 10.19. Found: C, 67.98, H, 8.63, N, 10.34.

$\left[\mathbf{L}^{\mathrm{Me}} \mathbf{F e}\left(\square^{1}-\mathbf{M e N H N H}_{2}\right)_{2}(\square-\mathbf{S})\right]\left(\mathbf{1}^{-2} \mathbf{H}_{2} \mathbf{N N H M e}\right)$. Methylhydrazine (50 $\square \mathrm{L}$, excess) was added through a microsyringe to a cold solution of $\mathbf{1}(100 \mathrm{mg}, 102 \square \mathrm{mol})$ in $5 \mathrm{~mL}$ of diethyl ether and the mixture was cooled to $-38{ }^{\circ} \mathrm{C}$. Red crystals formed $(14 \mathrm{mg}, 16 \%$ yield). The high sensitivity of this adduct as a solid and in solution at room temperature prevented complete characterization. IR (KBr): $3331 \mathrm{~cm}^{-1}(\mathrm{w}, \mathrm{N}-\mathrm{H})$. 


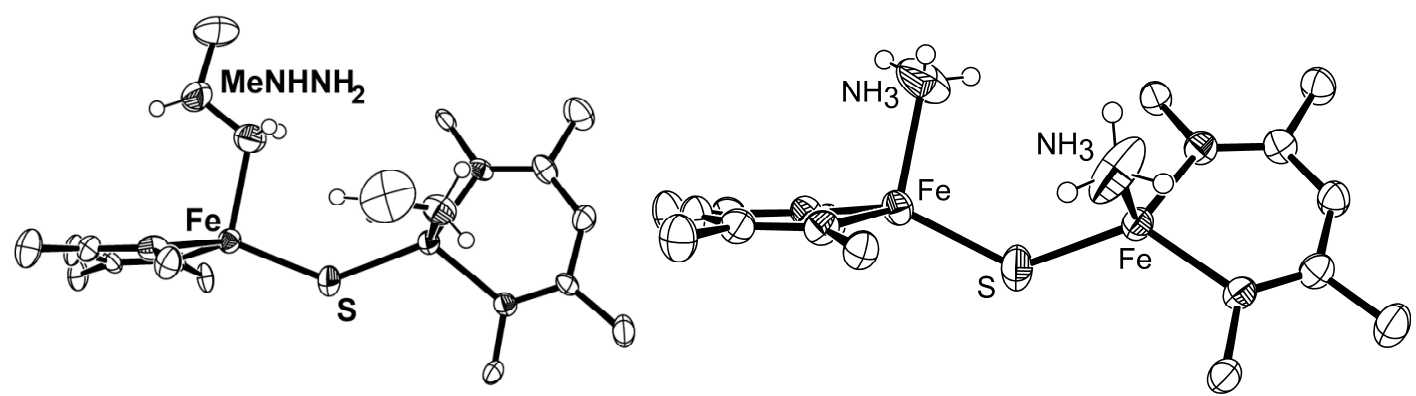

Figure S.2. Thermal ellipsoid plots of the X-ray crystal structures of $\mathbf{1} \cdot \mathbf{2} \mathbf{H}_{2} \mathbf{N N H M e}$ and $\mathbf{1} \cdot \mathbf{2} \mathbf{N H}_{\mathbf{3}}(50 \%$ ellipsoids, C-bound $\mathrm{H}$ atoms and aryl groups omitted).

$\left[\mathbf{L}^{\mathrm{Me}} \mathbf{F e}\left(\mathbf{N H}_{3}\right)_{2}(\mathrm{Q}-\mathbf{S})\right]\left(\mathbf{1} \cdot \mathbf{2} \mathbf{N H}_{3}\right)$. Ammonia gas, passed through a Drierite column, was condensed from a calibrated volume bulb $(294 \mathrm{~K}, 69.4 \mathrm{~mL}, 420 \mathrm{mBar}$, excess of 10 equivalents) into a tube containing a solution of $\mathbf{1}(119 \mathrm{mg}, 122 \square \mathrm{mol})$ in $4 \mathrm{~mL}$ of diethyl ether, at $77 \mathrm{~K}$. After warming the solution to room temperature and stirring for $5 \mathrm{~min}$, it was cooled to $-38{ }^{\circ} \mathrm{C}$ to obtain red crystals (103 $\mathrm{mg}$ in two crops, $84 \%$ yield). ${ }^{1} \mathrm{H}$ NMR $\left(\mathrm{C}_{6} \mathrm{D}_{6}\right): \square 11.7(0.4,2 \mathrm{H}, p-\mathrm{CH}), 8.4(3,4 \mathrm{H}, m-\mathrm{CH}), 2.2\left(3,18 \mathrm{H},{ }^{\mathrm{i}} \mathrm{PrCH}_{3}, \mathrm{NH}_{3}\right),-5.2(0.5$, 12H, $\left.{ }^{\mathrm{P} r C H} \mathrm{CH}_{3}\right),-7.5(1 \mathrm{H}, \mathrm{\square}-\mathrm{CH}),-8.2\left(3,4 \mathrm{H},{ }^{\mathrm{i}} \mathrm{PrCH}\right),-15.7\left(0.6,6 \mathrm{H}, \mathrm{\square}-\mathrm{CH}_{3}\right)$; IR $(\mathrm{KBr})$ : $3381 \mathrm{~cm}^{-1}(\mathrm{w}, \mathrm{N}-\mathrm{H})$; $\square_{\text {eff }}($ Evans $)=4.1(3) \square_{\mathrm{B}}$; Vis (toluene): $492 \mathrm{~nm}\left(1890 \mathrm{M}^{-1} \mathrm{~cm}^{-1}\right)$. The instability of this compound at room temperature prevented successful microanalysis.

Reaction of 1 with phenylhydrazine. Isolation of $\left(\mathrm{L}^{\mathrm{Me}} \mathrm{Fe}\right)_{2}(\square-\mathrm{S})\left(\square-\mathrm{PhNNH}_{2}\right)(2)$. To a stirring solution of $1(151 \mathrm{mg}, 154 \square \mathrm{mol})$ in $4 \mathrm{~mL}$ of diethyl ether was added phenylhydrazine ( $23 \square \mathrm{L}, 0.23 \mathrm{mmol}, 1.5$ equiv) via a microsyringe at room temperature. After ten minutes the solution had turned green. The solution was filtered through Celite and concentrated to $1 \mathrm{~mL}$ under vacuum. Cooling to $-38^{\circ} \mathrm{C}$ afforded dark green crystals (69 mg in two crops, $41 \%$ yield). ${ }^{1} \mathrm{H}$ NMR $\left(\mathrm{C}_{6} \mathrm{D}_{6}\right)$ : $\square 36.0(2,2 \mathrm{H}, p-\mathrm{CH}), 24.9(2,2 \mathrm{H}, p$ $\mathrm{CH}), 20.1\left(3,6 \mathrm{H}, \square-\mathrm{CH}_{3}\right), 18.9\left(3,6 \mathrm{H}, \square-\mathrm{CH}_{3}\right), 9.5\left(5 \mathrm{H}, \mathrm{C}_{6} \mathrm{H}_{5}\right), 8.3(1 \mathrm{H}, \square-\mathrm{CH}), 8.1(1 \mathrm{H}$, Q-CH), $3.5(3,4 \mathrm{H}, m-\mathrm{CH}), 3.3(3,4 \mathrm{H}, m-\mathrm{CH}), 1.1\left(4,12 \mathrm{H},{ }^{\mathrm{i}} \mathrm{PrCH}_{3}\right), 0.1\left(6,12 \mathrm{H},{ }^{\mathrm{i}} \mathrm{PrCH}_{3}\right)$, 
-3.1 (3, 12H, $\left.{ }^{\mathrm{PrCH}} \mathrm{CH}_{3}\right),-5.3\left(2,4 \mathrm{H},{ }^{\mathrm{i}} \mathrm{PrCH}\right),-7.1\left(2,4 \mathrm{H},{ }^{\mathrm{i}} \mathrm{PrCH}\right),-11.1\left(2,12 \mathrm{H},{ }^{\mathrm{i}} \mathrm{PrCH}_{3}\right)$.

The complexity of the spectrum prevented us from assigning all of the resonances. IR $(\mathrm{KBr}): 3240 \mathrm{~cm}^{-1}(\mathrm{w}, \mathrm{N}-\mathrm{H}) ; \square_{\mathrm{eff}}($ Evans $)=3.5(3) \square_{\mathrm{B}} ;$ Vis (toluene $): 431 \mathrm{~nm}\left(7260 \mathrm{M}^{-1} \mathrm{~cm}^{-}\right.$

$\left.{ }^{1}\right), 645 \mathrm{~nm}\left(4420 \mathrm{M}^{-1} \mathrm{~cm}^{-1}\right)$. Anal. Calcd for $\mathrm{C}_{67} \mathrm{H}_{99} \mathrm{~N}_{6} \mathrm{SFe}_{2}\left(2 \cdot \mathrm{Et}_{2} \mathrm{O}\right): \mathrm{C}, 71.28, \mathrm{H}, 8.72, \mathrm{~N}$, 7.24. Found: C, 70.74, H, 9.11, N, 6.89.

\section{Figure S.3}
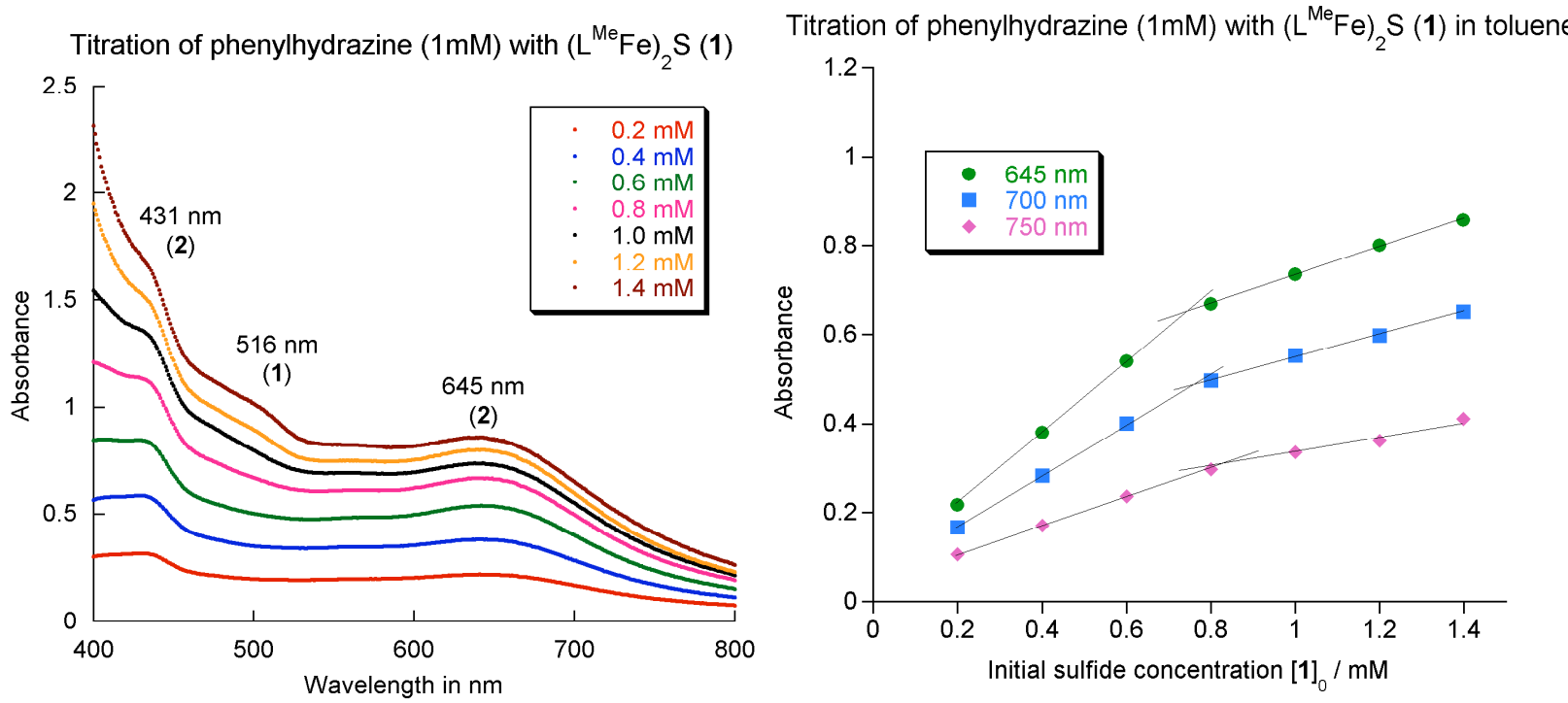
Reaction stoichiometry. The diiron(II) sulfide complex $1\left(\square_{\max }=516 \mathrm{~nm}\right.$, orange) and the mixed valence complex $2\left(\square_{\max }=431 \mathrm{~nm}\right.$ and $645 \mathrm{~nm}$, green $)$ absorb at different wavelengths in the visible region. This difference was used to investigate the reaction stoichiometry between phenylhydrazine (colorless after two recrystallizations) and compound $\mathbf{1}$ in toluene solution. Samples of equal total volume were prepared maintaining a constant phenylhydrazine concentration of $1 \mathrm{mM}$ and varying the initial concentration of sulfide (1) between 0 and $1.5 \mathrm{mM}$. A $1 \mathrm{mM}$ solution of phenylhydrazine in toluene was used as a blank. Spectra were recorded 20 minutes after sample preparation to allow the reaction to complete.

Figure S.4

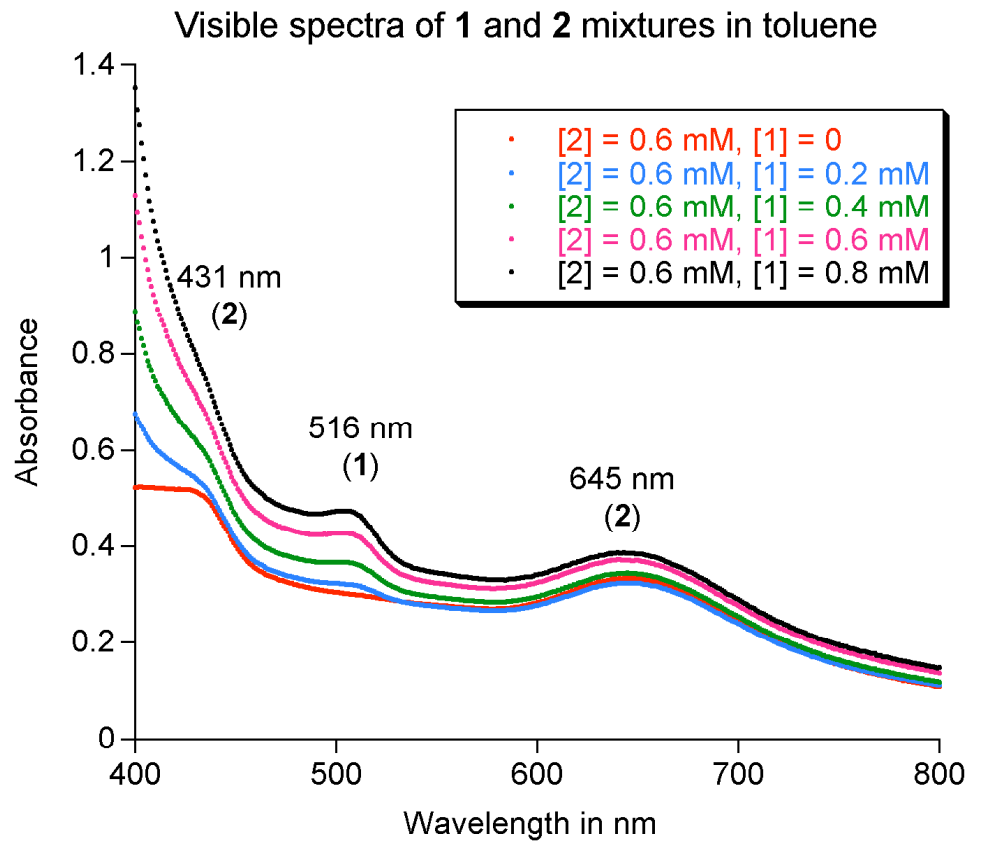

Upon mixing a limiting amount of 1 with phenylhydrazine, the peaks at 431 and 645 nm evidence the formation of complex 2 (Figure S.3). The absorption intensities are consistent with roughly $90 \%$ yield of $\mathbf{2}$. When an excess of free diiron(II) sulfide (1) is present, its presence is highlighted by a new peak at $516 \mathrm{~nm}$ as shown in Figure S.3. 
Similar spectra were obtained in a different experiment when authentic samples of complexes $\mathbf{1}$ and $\mathbf{2}$ were mixed (Figure S.4). Plots of absorbance as a function of initial sulfide concentration are shown in Figure S.3 (right). The solid lines shown were calculated from the earliest and latest data points. The intersection of the lines occurs at $[1]_{0}=0.75 \pm 0.12 \mathrm{mM}$. Because the initial phenylhydrazine concentration was kept constant at $1 \mathrm{mM}$, this shows that 1 reacts completely with $1.4 \pm 0.2$ equivalents of phenylhydrazine.

Reaction byproducts. The reaction was repeated by mixing 1 and phenylhydrazine in toluene in a sealed tube. After $30 \mathrm{~min}$ stirring at room temperature, aniline and ammonia could be detected by GC/MS. However, we were concerted about quantification given the potential decomposition of phenylhydrazine in the GC injector. Therefore, in an an identical 30-minute reaction, volatile materials were vacuum transferred into a second Schlenk bomb kept at liquid nitrogen temperature. This was treated with excess of hydrochloric acid ( $0.5 \mathrm{M}$ solution in diethyl ether), warmed to room temperature, and the solvent was removed under vacuum. The remaining white solid was dissolved in phosphate buffer $(\mathrm{pH}=7.0(2))$ and analyzed for ammonium ion by the indophenol method according to the literature procedure. ${ }^{3}$ The absorbance reading was compared against a calibration curve made from authentic ammonium chloride standards.

Table S.1. Recovery of ammonia in the reaction of $\mathbf{1}$ with phenylhydrazine.

\begin{tabular}{cccc}
\hline Initial 1 & Initial $\mathrm{PhNHNH}_{2}$ & Ammonia detected & Equivalents formed per 1 \\
\hline $68 \square \mathrm{mol}$ & $102 \square \mathrm{mol}$ & $16 \square \mathrm{mol}$ & 0.23 \\
$197 \square \mathrm{mol}$ & $295 \square \mathrm{mol}$ & $93 \square \mathrm{mol}$ & 0.47 \\
$153 \square \mathrm{mol}$ & $229 \square \mathrm{mol}$ & $61 \square \mathrm{mol}$ & 0.39 \\
\hline
\end{tabular}


X-ray crystallography. Crystalline samples were grown in the glove box from pentane solutions at $-38{ }^{\circ} \mathrm{C}$. Crystals were rapidly mounted under Paratone- 8277 onto glass fibers, and immediately placed in a cold nitrogen stream at $-80{ }^{\circ} \mathrm{C}$ on the X-ray diffractometer. The X-ray intensity data were collected on a standard Bruker-axs SMART CCD Area Detector System equipped with a normal focus molybdenum-target $\mathrm{X}$-ray tube operated at $2.0 \mathrm{~kW}(50 \mathrm{kV}, 40 \mathrm{~mA})$. Frames were integrated to a maximum $2 \square$ angle of $56.5^{\circ}$ with the Bruker-axs SAINT program. The final unit cell parameters (at -80 ${ }^{\circ} \mathrm{C}$ ) were determined from the least-squares refinement of three-dimensional centroids of $>4000$ reflections for each crystal. Data were corrected for absorption with the SADABS program.

Structures were solved by direct methods using Sir92 (WinGX v1.63.02) and refined employing full-matrix least-squares on $F^{2} . \mathrm{Z}$ values were as expected for one full molecule in the asymmetric unit. All non-H atoms in all three complexes were refined with anisotropic thermal parameters. Hydrogen atoms were included in idealized positions.

EPR Spectroscopy. The EPR spectrum of 2 (Figure 3, text) was collected at $9 \mathrm{~K}$, as a toluene glass. Conditions: $9.622 \mathrm{GHz} ; 2 \square \mathrm{W}$ microwave power; $1 \mathrm{mT}$ modulation. The best simulation had $g_{1}=1.99\left(\square_{1}=0.004\right), g_{2}=1.926\left(\square_{2}=0.0190\right)$, and $g_{3}=1.66\left(\square_{3}=\right.$ $0.024)$, where the $\square_{i}$ represents the gaussian width of distributed $g$-values. If the exchange coupling constant, $J$, is large compared to the zero-field splittings of the ferric and ferrous sites, the $g$ tensor of 2 is given by $g=(7 / 3) g\left(\mathrm{Fe}^{\mathrm{III}}\right)-(4 / 3) g\left(\mathrm{Fe}^{\mathrm{III}}\right){ }^{7}$ However, our studies of tetrahedral $\mathrm{LFe}^{\mathrm{II}}(\mathrm{\square}-\mathrm{Cl})_{2} \mathrm{Li}(\text { thf })_{2}{ }^{8}$ indicate a substantial zero-field (ZFS) splitting of $D \square 15 \mathrm{~cm}^{-1}$, suggesting that mixing by ZFS terms could affect the $g$-values of 2. ${ }^{9}$ The resolution of the $4.2 \mathrm{~K}$ Mössbauer spectra of solid 2 suffers from spin-spin relaxation effects; currently we are preparing dilute, $1 \mathrm{mM},{ }^{57} \mathrm{Fe}$-enriched samples in toluene which should allow us to analyze the hyperfine interactions of $\mathbf{2}$. 
Figure S5. Mössbauer spectra of $\mathbf{1}$ in benzene ( $4.2 \mathrm{~K}$ ) recorded in zero field (A) and in a parallel field of $7.0 \mathrm{~T}$ (B). Solid line in (A) is a simulation of a quadrupole doublet with $\square \mathrm{E}_{\mathrm{Q}}=0.58 \mathrm{~mm} / \mathrm{s}$ and $\mathrm{Q}=0.86 \mathrm{~mm} / \mathrm{s}$ (versus Fe metal at $298 \mathrm{~K}$ ). The simulation in (B) assumes two identical diamagnetic sites with $\square \mathrm{E}_{\mathrm{Q}}<0$ and $\mathrm{Q}=0.6$. The low energy feature cannot be fitted with diamagnetic sites, even if the sites are allowed to be inequivalent (but compatible with the spectrum of (A)). The broadened low-energy feature requires the presence of a positive internal field of $0.3-0.5 \mathrm{~T}$. A similar positive internal field is also required to simulate the $100 \mathrm{~K}$ and $140 \mathrm{~K}$ spectra. Nearly identical spectra are observed for polycrystalline 1, except for the value of $\square=0.81 \mathrm{~mm} / \mathrm{s}$ which differs from that found in solution. We do not know which crystalline form of $\mathbf{1}$ (see below) was represented in our polycrystalline sample. Explanation of the positive internal field in the high-field spectra of $\mathbf{1}$ will require a better understanding of the spin coupling for trigonal ferrous diketiminate sites. As discussed by Andres et al., the near orbital degeneracy of the ground state produces a very unusual ground state where a spin doublet (loosely the $\mathrm{M}_{\mathrm{S}}= \pm 2$ levels) is separated from the next spin doublet by ca. $150 \mathrm{~cm}^{-1} .{ }^{10}$

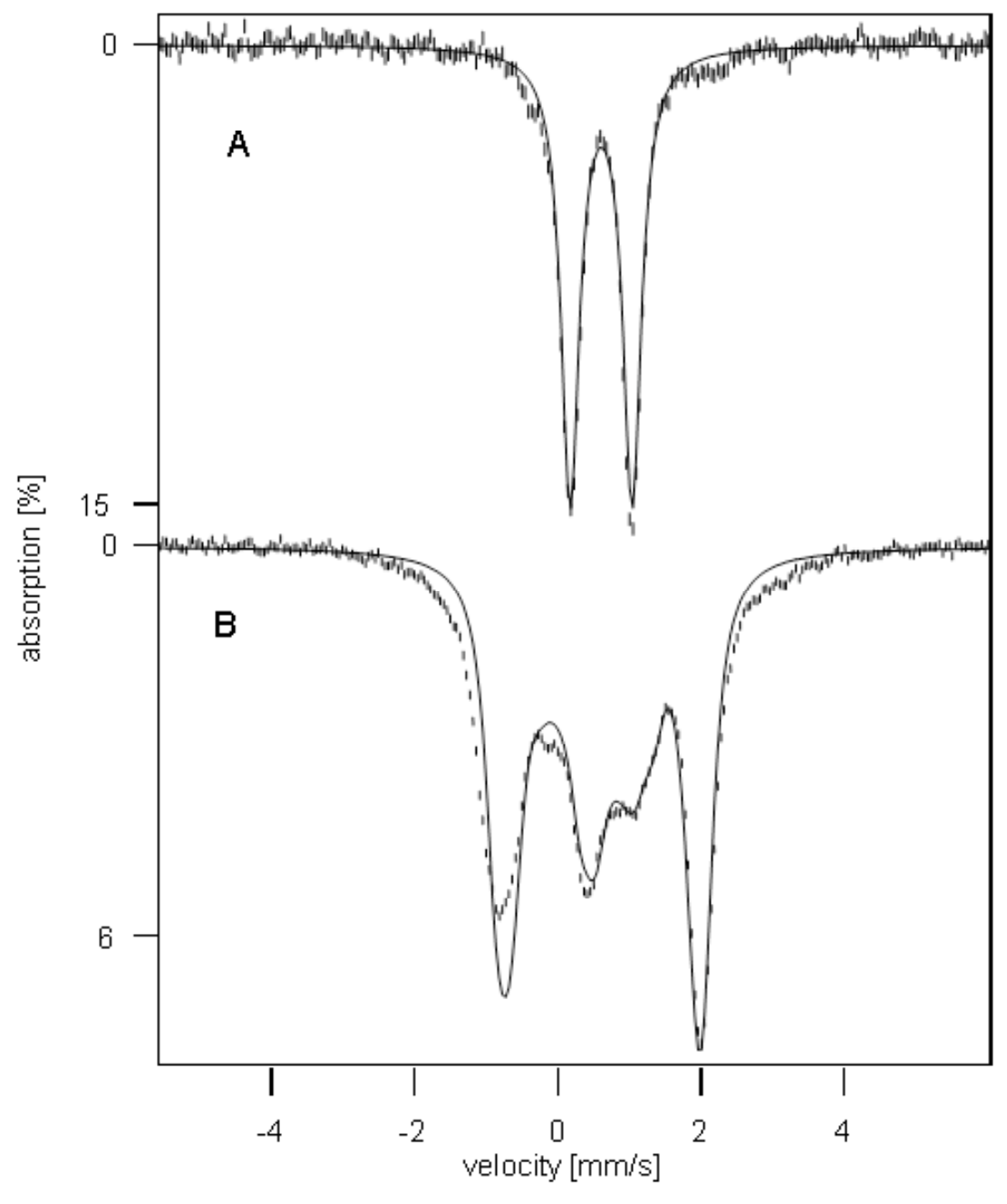


Crystal Structures of Compound 1. Crystals grown from pentane/ether mixtures gave single crystals with three different unit cells/space groups. The packing was distinctly different in each structure, and in each case the sulfide was at half occupancy, disordered over two symmetry-equivalent positions. In each case, refinements with full-occupancy sulfur had large thermal parameters on sulfur, showing that there is only one bridging sulfide (this is also confirmed by microanalysis, the iron(II) oxidation state from Mössbauer spectroscopy, and the single sulfide found in the Lewis base adducts).

holjv08 had an ordered pentane/diethyl ether solvent, and the dinuclear complex was split by a mirror plane containing the $\mathrm{Fe}_{2} \mathrm{~S}$ unit, and also had an inversion center. holjv21 had a disordered solvent molecule that failed to give reasonable bond distances and angles; the SQUEEZE function within PLATON was used to remove the solvent electron density ( $21 e^{-} /$cell, $308.3 \AA^{3}$ ) before final refinement, improving $R$ by $1 \%$. The molecule had an inversion center in the center. holjv24 had no solvent in the lattice, but also had an inversion center between the two iron atoms. Details are listed in Table S.2.

Both holjv08 and holjv24 refined to give large, anisotropic thermal parameters on the iron and sulfur atoms, suggesting substantial disorder in the positions of the $\mathrm{Fe}_{2} \mathrm{~S}$ core. This is not merely disorder between the two inversion partners, because each halfoccupancy sulfur is disordered. Rather, these structures suggest that the $\mathrm{Fe}_{2} \mathrm{~S}$ core adopts a number of conformations in the crystal lattice. Figure $S-6$ gives the refined parameters, but the values and esd's from structures holjv08 and holjv28 must be viewed with extreme skepticism. In holjv21, the core is much more ordered, and therefore the metrical parameters from this structure are listed in the text.

Note that the zero field Mössbauer spectra of $\mathbf{1}$ indicate equivalent iron environments. One doublet with narrow lines $(\square=0.29 \mathrm{~mm} / \mathrm{s}$ full width at half maximum) is observed, suggesting that crystals of the type in holjv21 were not present in the Mössbauer sample; given the large Fe-S bond difference in holjv21 we expect different Mossbauer parameters for the two sites.

Table S.2. Selected data for crystal structures of $\mathbf{1}$.

\begin{tabular}{|l|l|l|l|}
\hline Structure & holjv08 & holjv21 & holjv24 \\
\hline Crystal system & Monoclinic & Triclinic & Monoclinic \\
\hline Space group & $C 2 / m$ & $P \overline{1}$ & $C 2 / c$ \\
\hline$a(\AA)$ & $16.5158(10)$ & $9.1867(4)$ & $24.679(2)$ \\
\hline$b(\AA)$ & $19.3561(10)$ & $13.3083(6)$ & $13.284(1)$ \\
\hline$c(\AA)$ & $13.1935(7)$ & $13.6383(7)$ & $17.896(1)$ \\
\hline$\square\left(^{\circ}\right)$ & 90 & $87.887(1)$ & 90 \\
\hline$\square\left(^{\circ}\right)$ & $126.177(1)$ & $78.346(1)$ & $102.504(1)$ \\
\hline$\square\left(^{\circ}\right)$ & 90 & $77.745(1)$ & 90 \\
\hline$V\left(\AA^{3}\right)$ & $3404.5(3)$ & $1595.8(1)$ & $5727.8(7)$ \\
\hline$Z$ & 2 & 1 & 4 \\
\hline data/parameters & $4218 / 176$ & $7228 / 298$ & $6867 / 308$ \\
\hline GOF & 1.033 & 1.067 & 1.151 \\
\hline R $(\%)$ & 4.49 & 7.50 & 8.48 \\
\hline solvent? & yes (ordered) & yes (SQUEEZE) & no \\
\hline disorder of S? & yes & no & yes \\
\hline symmetry within 1 & mirror, inversion & inversion & inversion \\
\hline
\end{tabular}


Figure S-6. Thermal-ellipsoid plots of 1. Bond distances in $\AA$; bond angles in degrees.

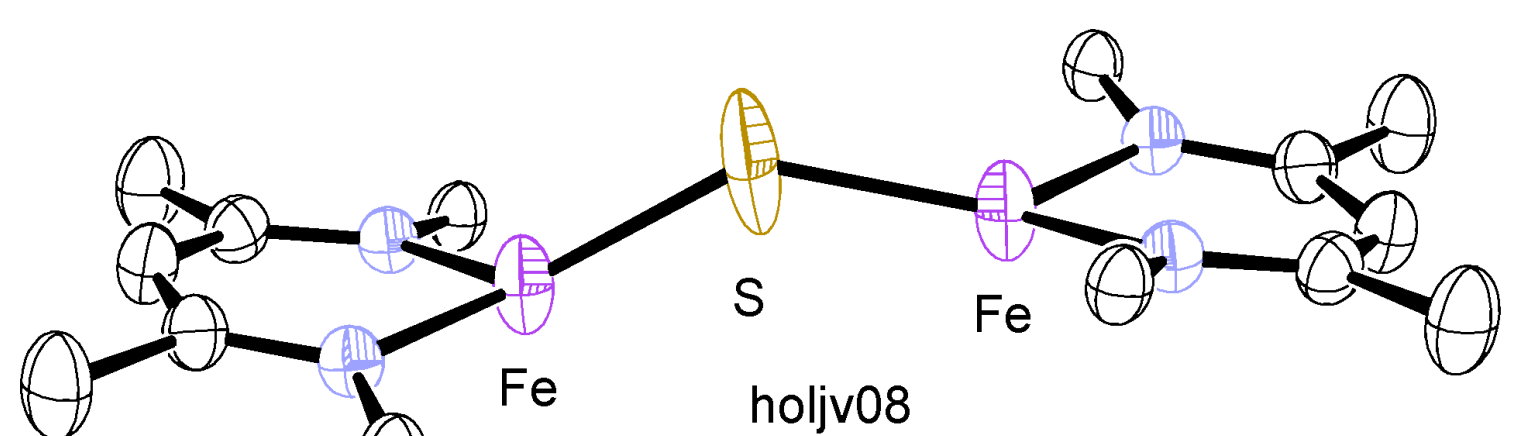

holjv08

Fe-S 2.186(2)?, 2.239(2)?

Fe-S-Fe 139.0(1)?
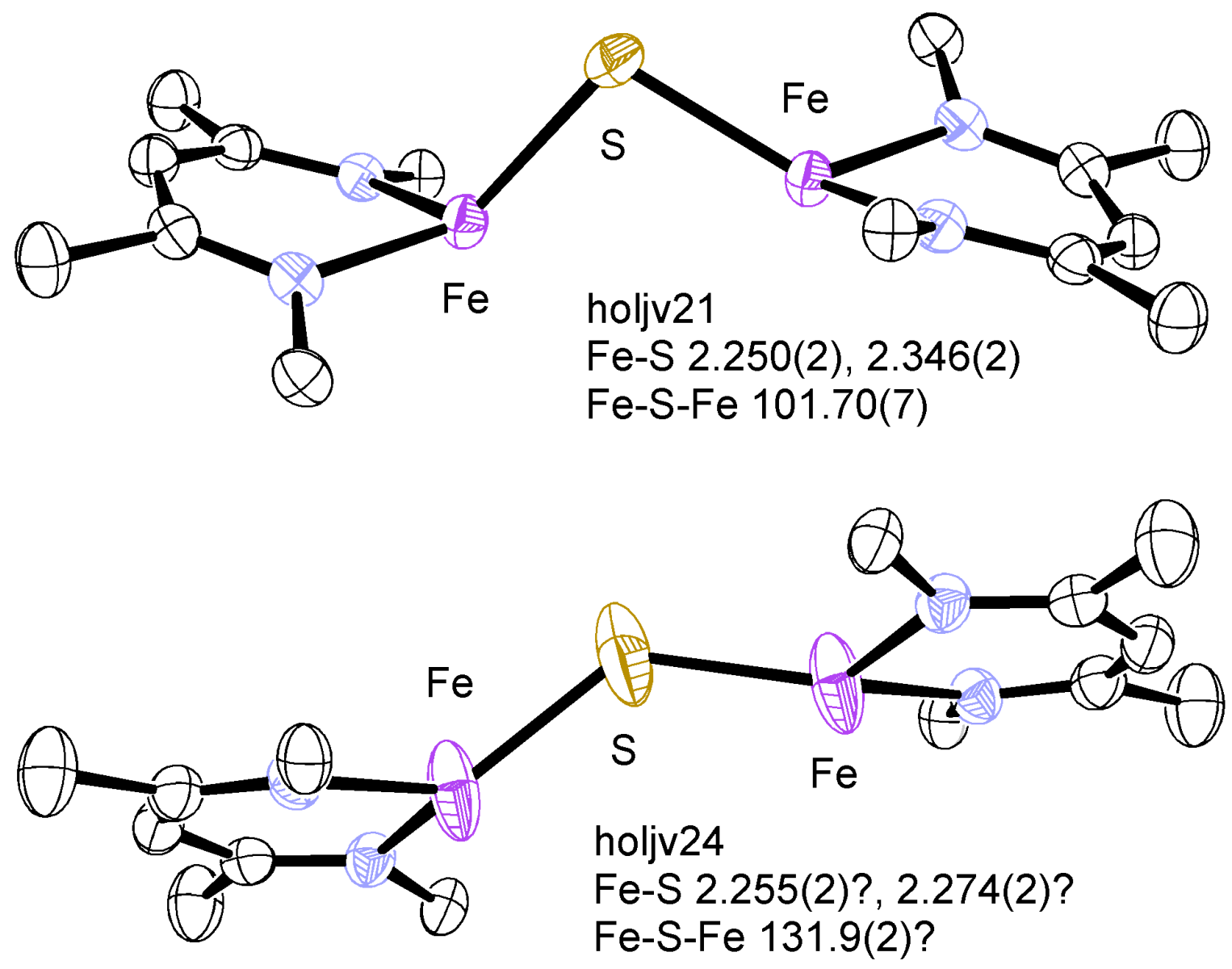
The pyramidalization parameter $\square$ This concept borrows from a similar $\square$ value used in 5-coordinate complexes to quantify intermediates between square pyramidal and trigonal bipyramidal geometries (see Addison, A. W.; Rao, T. N.; Reedijk, J.; van Rijn, J.; Verschoor, G. C. J. Chem. Soc., Dalton Trans. 1984, 1349-1356). For four-coordinate complexes, we define $\square$ as the normalized sum of the basal ligand-basal ligand angles minus the sum of the basal ligand-axial ligand angles:

$$
\square=\frac{\square(\text { basal } \square M \square \text { basal }) \square \square(\text { basal } \square M \square \text { axial })}{90^{\circ}}
$$

- For a perfectly tetrahedral complex, this gives $\square=[(109.5 * 3)-(109.5 * 3)] / 90=0$.

- For a perfect trigonal pyramid, this gives $\square=[(120 * 3)-(90 * 3)] / 90=1$.

- The axial ligand is the ligand that, when defined as such, gives the largest value of $\square$ (smallest sum of angles to this atom).

- Note that this simple definition is not general to other four-coordinate geometries (seesaw, square planar). For other symmetry measures of 4-coordinate structures, see Cirera, J.; Alemany, P.; Alvarez, S. Chem. Eur. J. 2004, 10, 190 and references therein.

Table S.3. Pyramidalization of four-coordinate structures as measured by $\square$ method. $\square^{\mathrm{Fe}}=$ Sum of angles around metal center that include apical ligand (minimum sum); $\square^{\mathrm{Fe}}=$ Sum of angles around metal and the other ligands (trigonal base sum). $\mathrm{L}^{\mathrm{Me}}=$ diketiminate ligand described in the text.

\begin{tabular}{|c|c|c|c|c|c|}
\hline Compound & apical ligand & $\square_{\mathrm{a}}^{\mathrm{Fe}}$ & $\square_{\mathrm{b}}^{\mathrm{Fe}}$ & $\square_{b}^{\mathrm{Fe}}-\square_{\mathrm{a}}^{\mathrm{Fe}}$ & $\square=\left(\square_{b}^{\mathrm{Fe}}-\square_{\mathrm{a}}^{\mathrm{Fe}}\right) / 90$ \\
\hline FeMoco belt region & \multirow[t]{11}{*}{$\overline{\square-X}$} & 306.968 & 346.453 & 39.485 & 0.4387 \\
\hline \multirow[t]{10}{*}[\mathrm{Fe}_{3}\mathrm{S}_{3}(\square-\mathrm{X})\mathrm{S}_{3}\mathrm{Fe}_{3}\mathrm{S}_{3}]{} & & 306.243 & 346.709 & 40.466 & 0.4496 \\
\hline & & 305.195 & 347.408 & 42.213 & 0.4690 \\
\hline & & 304.980 & 347.989 & 43.009 & 0.4779 \\
\hline & & 305.100 & 347.690 & 42.590 & 0.4732 \\
\hline & & 306.801 & 346.600 & 39.799 & 0.4422 \\
\hline & & 304.352 & 348.274 & 43.922 & 0.4880 \\
\hline & & 305.413 & 347.440 & 42.027 & 0.4670 \\
\hline & & 306.704 & 346.583 & 39.879 & 0.4431 \\
\hline & & 306.312 & 346.735 & 40.423 & 0.4491 \\
\hline & & 306.931 & 346.274 & 39.343 & 0.4371 \\
\hline \multirow[t]{2}{*}{ FeMoco average } & \multirow[t]{2}{*}{$\square-X$} & \multirow[t]{2}{*}{ - } & \multirow[t]{2}{*}{ - } & $41.2 \pm 2.7$ & $0.458 \pm 0.030$ \\
\hline & & & & std.dev.= & std. dev. $=0.017$ \\
\hline Borovik, [Fe1 $\left.{ }^{\mathrm{iPr}}\right]$ JACS 1996, & $\mathrm{R}_{3} \mathrm{~N}$ & 250.25 & 356.11 & 105.86 & 1.176 \\
\hline 118,6084 & & & & & \\
\hline \multirow{3}{*}{$\begin{array}{c}\left(\mathrm{L}^{\mathrm{Me}} \mathrm{Fe}\right)_{2}(\square-\mathrm{S})\left(\mathrm{NH}_{3}\right)_{2} \\
\left(\mathrm{~L}^{\mathrm{Me}} \mathrm{Fe}\right)_{2}(\square-\mathrm{S})\left(\mathrm{Me}_{2} \mathrm{NNH}_{2}\right)_{2}\end{array}$} & \multirow{3}{*}{$\begin{array}{c}\mathrm{NH}_{3} \\
\mathrm{Me}_{2} \mathrm{NNH}_{2}\end{array}$} & 312.06 & 342.07 & 30.01 & 0.3334 \\
\hline & & 312.39 & 343.42 & 31.03 & 0.3448 \\
\hline & & 315.85 & 340.20 & 24.35 & 0.2706 \\
\hline \multirow[t]{2}{*}{$\left(\mathrm{L}^{\mathrm{Me}} \mathrm{Fe}\right)_{2}(\square-\mathrm{S})\left(\mathrm{MeNHNH}_{2}\right)_{2}$} & $\mathrm{MeNHNH}_{2}$ & 295.81 & 351.81 & 56.00 & 0.6222 \\
\hline & $\mathrm{MeNHNH}_{2}$ & 311.97 & 343.09 & 31.12 & 0.3458 \\
\hline \multirow{3}{*}{$\begin{array}{l}\left(\mathrm{L}^{\mathrm{Me}} \mathrm{Fe}\right)_{2}(\square-\mathrm{S})\left(\square^{1}-\mathrm{CH}_{3} \mathrm{CN}\right) \\
\left(\mathrm{L}^{\mathrm{Me}} \mathrm{Fe}\right)_{2}(\mathrm{\square}-\mathrm{S})\left(\square-\mathrm{PhNH}_{2}\right)\end{array}$} & $\mathrm{N}^{\mathrm{L}}$ & 321.06 & 335.79 & 14.73 & 0.1637 \\
\hline & $\mathrm{N}^{\mathrm{L}}-\mathrm{Fe}^{\mathrm{III}}$ & 320.18 & 337.13 & 16.95 & 0.1883 \\
\hline & $\mathrm{N}^{\mathrm{L}}-\mathrm{Fe}^{\mathrm{II}}$ & 324.37 & 333.36 & 8.990 & 0.0999 \\
\hline \multirow{4}{*}{$\begin{array}{c}\mathrm{L}^{\mathrm{Me}} \mathrm{FeCl}_{2} \mathrm{Li}(\mathrm{THF})_{2} \\
\text { (different structures) }\end{array}$} & $\mathrm{N}^{\mathrm{L}}$ & 326.80 & 333.39 & 6.590 & 0.0732 \\
\hline & $\mathrm{N}^{\mathrm{L}}$ & 327.30 & 332.67 & 5.370 & 0.0597 \\
\hline & $\mathrm{N}^{\mathrm{L}}$ & 325.99 & 332.64 & 6.650 & 0.0739 \\
\hline & $\mathrm{N}^{\mathrm{L}}$ & 327.98 & 330.67 & 2.690 & 0.0299 \\
\hline $\mathrm{L}^{\mathrm{Me}} \mathrm{FeCl}_{2} \mathrm{Li}\left(\mathrm{Et}_{2} \mathrm{O}\right)_{2}$ & $\mathrm{~N}^{\mathrm{L}}$ & 328.02 & 330.83 & 2.810 & 0.0312 \\
\hline
\end{tabular}


Table S.4. Pyramidalization of literature four-coordinate structures by $\square$ method

\begin{tabular}{|c|c|c|c|}
\hline Compound & $\begin{array}{l}\text { apical } \\
\text { ligand }\end{array}$ & $\bar{\square}$ & Ref. \\
\hline \multicolumn{4}{|l|}{ Monometallic } \\
\hline$\left[(\mathrm{MeS})_{4} \mathrm{Fe}\right]\left[\mathrm{NEt}_{4}\right]$ & $\mathrm{SMe}$ & 0.000 & 11 \\
\hline $\mathrm{Ba}\left[\left(\mathrm{HO}\left(\mathrm{CH}_{2}\right)_{2} \mathrm{~S}\right)_{4} \mathrm{Fe}\right]$ & $\begin{array}{l}\mathrm{SCH}_{2} \mathrm{CH}_{2} \\
\mathrm{OH}\end{array}$ & 0.001 & 12 \\
\hline$\left[(\mathrm{EtS})_{4} \mathrm{Fe}\right]\left[\mathrm{N}(\mathrm{nPr})_{4}\right]$ & SEt & 0.004 & 11 \\
\hline$\left[(p-\mathrm{TolS})_{4} \mathrm{Fe}\right]\left[\mathrm{NEt}_{4}\right]$ & STol & 0.025 & 13 \\
\hline$\left[(\mathrm{PhS})_{4} \mathrm{Fe}\right]\left[\mathrm{NEt}_{4}\right]$ & $\mathrm{SPh}$ & 0.052 & 11 \\
\hline$\left[\left(\mathrm{N}\left(\mathrm{CH}_{2} \mathrm{CH}_{2} \mathrm{~S}\right)_{3}\left(\square^{1}-\mathrm{CyNC}\right) \mathrm{Fe}\right)_{2} \mathrm{Fe}\right]\left(\mathrm{H}_{2} \mathrm{O}\right)^{*}$ & -S-SR & 0.057 & 14 \\
\hline$\left[(\mathrm{PhS})_{4} \mathrm{Fe}\right]\left[\mathrm{PPh}_{4}\right]$ & $\mathrm{SPh}$ & 0.093 & 15 \\
\hline$\left[(\mathrm{dith})_{2} \mathrm{Fe}\right]\left[\mathrm{PPh}_{4}\right]$ & $\mathrm{S}($ dith) & 0.150 & 15 \\
\hline$\left[(\mathrm{MesS})_{4} \mathrm{Fe}\right]\left[\mathrm{PPh}_{4}\right]$ & SMes & 0.234 & 16 \\
\hline \multicolumn{4}{|l|}{ Bimetallic } \\
\hline$\left[\left(\mathrm{Cl}_{3} \mathrm{Fe}\right)_{2}(\square-\mathrm{O})\right]\left[\mathrm{PhCH}_{2} \mathrm{PPh}_{3}\right]$ & $\mathrm{Cl}$ & $0.04 \pm 0.02$ & 17 \\
\hline$\left[\left(\mathrm{Br}_{3} \mathrm{Fe}\right)_{2}(\square-\mathrm{O})\right]\left[\mathrm{Cp}_{2} \mathrm{Fe}\right]$ & $\mathrm{Cl}$ & $0.05 \pm 0.00$ & 18 \\
\hline$\left[\left(\mathrm{Cl}_{3} \mathrm{Fe}\right)_{2}(\square-\mathrm{O})\right]\left[\mathrm{Cp}_{2} \mathrm{Fe}\right]$ & $\mathrm{Cl}$ & $0.06 \pm 0.00$ & 19 \\
\hline$\left[\left(\mathrm{Cl}_{3} \mathrm{Fe}\right)_{2}(\square-\mathrm{O})\right]\left[\mathrm{PPh}_{4}\right]\left(\mathrm{CH}_{2} \mathrm{Cl}_{2}\right)$ & $\mathrm{Cl}$ & $0.07 \pm 0.00$ & 20 \\
\hline$\left[\left(\square^{1}-\mathrm{EtS}\right)_{2} \mathrm{Fe}_{2}(\square-\mathrm{EtS})\right]\left[\mathrm{NEt}_{4}\right]$ & D-SEt & $0.15 \pm 0.00$ & 27 \\
\hline$\left[\left\{(\mathrm{PhS})_{3} \mathrm{Fe}\right\}_{2}(\square-\mathrm{O})\right]\left[\mathrm{NEt}_{4}\right]$ & $\mathrm{PhS}$ & $0.15 \pm 0.00$ & 21 \\
\hline$\left[\mathrm{Fe}_{2}\left(\square-1,2 \text {-dimercaptoC } \mathrm{H}_{4}\right)_{3}\right]\left[\mathrm{NEt}_{4}\right]\left(\mathrm{CH}_{3} \mathrm{CN}\right)$ & G-SR & $0.20 \pm 0.03$ & 27 \\
\hline$\left[\left(\square^{1}-\mathrm{iPrS}\right)_{2} \mathrm{Fe}_{2}(\square-\mathrm{iPrS})_{2}\right]\left[\mathrm{NMe}_{4}\right]$ & ○-SiPr & $0.26 \pm 0.00$ & 22 \\
\hline \multicolumn{4}{|l|}{ Cubanes } \\
\hline$\left[\left(\square^{1}-\mathrm{HS}\right)_{4} \mathrm{Fe}_{4}(\square-\mathrm{S})_{4}\right]\left[\mathrm{NEt}_{4}\right] \mathrm{Cl}$ & $\square-S$ & $0.12 \pm 0.00$ & 23 \\
\hline$\left[\mathrm{Br}_{4} \mathrm{Fe}_{4}(\square-\mathrm{S})_{4}\right]\left[\mathrm{PPh}_{4}\right]$ & $\square-\mathrm{S}$ & $0.16 \pm 0.01$ & 24 \\
\hline$\left[\left(\square^{1}-\mathrm{HO}\left(\mathrm{CH}_{2}\right)_{3} \mathrm{~S}\right)_{4} \mathrm{Fe}_{4}(\square-\mathrm{S})_{4}\right]\left[\mathrm{PPh}_{4}\right]\left(\mathrm{CH}_{3} \mathrm{CN}\right)$ & D-S & $0.16 \pm 0.02$ & 25 \\
\hline$\left[\mathrm{Cl}_{4} \mathrm{Fe}_{4}(\square-\mathrm{S})_{4}\right]\left[\mathrm{N}(\mathrm{nPr})_{4}\right]$ & $\square-\mathrm{S}$ & $0.16 \pm 0.02$ & 23 \\
\hline$\left[\left(\square^{1}-\mathrm{EtS}\right)_{4} \mathrm{Fe}_{4}(\square-\mathrm{S})_{4}\right]\left[\mathrm{NMe}_{4}\right]$ & $\square-\mathrm{S}$ & $0.18 \pm 0.00$ & 26 \\
\hline$\left[\left(\square^{1}-\mathrm{EtS}\right)_{4} \mathrm{Fe}_{4}(\square-\mathrm{EtS})_{4}\right]\left[\mathrm{NMe}_{4}\right]$ & $\square-S$ & $0.18 \pm 0.03$ & 27 \\
\hline$\left[\left(\square^{1}-\mathrm{BnS}\right)_{4} \mathrm{Fe}_{4}(\square-\mathrm{S})_{4}\right]\left[\mathrm{NEt}_{4}\right]$ & $\square-S$ & $0.18 \pm 0.06$ & 28 \\
\hline$\left[\mathrm{I}_{4} \mathrm{Fe}_{4}(\square-\mathrm{S})_{4}\right]\left[\mathrm{NMeBn}_{3}\right]$ & ๑-S & $0.21 \pm 0.07$ & 29 \\
\hline$\left[\left(\square^{1}-\mathrm{CyS}\right)_{4} \mathrm{Fe}_{4}(\square-\mathrm{S})_{4}\right]\left[\mathrm{NEt}_{4}\right]$ & $\square-\mathrm{S}$ & $0.22 \pm 0.04$ & 30 \\
\hline \multicolumn{4}{|l|}{ Heterocubanes } \\
\hline$\left[\left(\mathrm{iPr}_{3} \mathrm{PFe}\right)_{3}(\square-\mathrm{S})_{4} \mathrm{Mo}\left(1,2-\mathrm{C}_{6} \mathrm{Cl}_{4} \mathrm{O}_{2}\right)\left(\square^{1}-\mathrm{NCCH}_{3}\right)\right]$ & $\square-\mathrm{S}$ & $0.12 \pm 0.04$ & 31 \\
\hline $\begin{array}{c}{\left[\left(\square^{1}-\mathrm{EtS}\right)_{3} \mathrm{Fe}_{3}(\square-\mathrm{S})_{4} \mathrm{Mo}\left(\mathrm{Me}_{2} \mathrm{PCH}_{2} \mathrm{CH}_{2} \mathrm{PMe}_{2}\right)\left(\square^{1}-\right.\right.} \\
\mathrm{EtS})]\left[\mathrm{NEt}_{4}\right]\end{array}$ & G-S & $0.16 \pm 0.05$ & 32 \\
\hline $\begin{array}{c}{\left[\left(\square^{1}-\mathrm{Cl}\right)_{3} \mathrm{Fe}_{3}(\square-\mathrm{S})_{4} \mathrm{Mo}\left(3,6-\left(\mathrm{CH}_{2} \mathrm{CHCH}_{2}\right)-1,2-\right.\right.} \\
\left.\left.\mathrm{C}_{6} \mathrm{H}_{2} \mathrm{O}_{2}\right)\left(\square^{1}-\mathrm{THF}\right)\right]\left[\mathrm{NEt}_{4}\right]\end{array}$ & $\square-S$ & $0.17 \pm 0.02$ & 33 \\
\hline$\left[\left(\square^{1}-\mathrm{EtS}\right)_{3} \mathrm{Fe}_{3}(\square-\mathrm{S})_{4} \mathrm{Mo}(\mathrm{CO})_{3}\right]\left[\mathrm{NEt}_{4}\right]\left(\mathrm{CH}_{3} \mathrm{CN}\right)$ & $\square-S$ & $0.17 \pm 0.02$ & 34 \\
\hline$\left[\left(\square^{1}-\mathrm{Cl}\right)_{3} \mathrm{Fe}_{3}(\square-\mathrm{S})_{4} \mathrm{Mo}\left(1,2-\mathrm{C}_{6} \mathrm{Cl}_{4} \mathrm{O}_{2}\right)\left(\square^{1}-\mathrm{NCCH}_{3}\right)\right]\left[\mathrm{NEt}_{4}\right]$ & $\square-\mathrm{S}$ & $0.19 \pm 0.00$ & 35 \\
\hline$\left[\left(\square^{1}-\mathrm{HS}\right)_{3} \mathrm{Fe}_{3}(\square-\mathrm{S})_{4} \mathrm{MoTp}_{[}\left[\mathrm{NEt}_{4}\right]\right.$ & D-S & $0.20 \pm 0.05$ & 36 \\
\hline$\left[\left(\square^{1}-\mathrm{MesS}\right)_{3} \mathrm{Fe}_{3}(\square-\mathrm{S})_{4} \mathrm{Mo}(\mathrm{CO})_{3}\right]\left[\mathrm{NEt}_{4}\right]\left(\mathrm{CH}_{3} \mathrm{CN}\right)$ & (]-S & $0.21 \pm 0.03$ & 37 \\
\hline $\begin{array}{c}{\left[\left(\square^{1}-p-\mathrm{ClC}_{6} \mathrm{H}_{4} \mathrm{~S}\right)_{3} \mathrm{Fe}_{3}(\mathrm{\square}-\mathrm{S})_{4} \mathrm{Mo}\left(3,6-\left(\mathrm{CH}_{2} \mathrm{CHCH}_{2}\right)-1,2-\right.\right.} \\
\left.\left.\mathrm{C}_{6} \mathrm{H}_{2} \mathrm{O}_{2}\right)\left(\square^{1}-p-\mathrm{ClC}_{6} \mathrm{H}_{4} \mathrm{~S}\right)\right]\left[\mathrm{NEt}_{4}\right]\end{array}$ & $\square-\mathrm{S}$ & $0.29 \pm 0.08$ & 38 \\
\hline \multicolumn{4}{|l|}{ Other clusters (See Figure below) } \\
\hline \multirow[t]{2}{*}{$\mathbf{I}$} & $\mathrm{Fe}: \mathrm{Q-S}$ & $0.18 \pm 0.04$ & 39 \\
\hline & $\mathrm{Fe}^{\prime}: \mathrm{Q}-\mathrm{S}$ & $0.17 \pm 0.02$ & \\
\hline \multirow[t]{3}{*}{ II } & $\mathrm{Fe}: \mathrm{PEt}_{3}$ & $0.82 \pm 0.00$ & 40 \\
\hline & $\mathrm{Fe}^{\prime}: \mathrm{PEt}_{3}$ & $0.58 \pm 0.00$ & \\
\hline & $\mathrm{Fe}^{\prime \prime}: \mathrm{Cl}$ & $0.12 \pm 0.00$ & \\
\hline \multirow[t]{2}{*}{ III and IV } & $\mathrm{Fe}: \mathrm{PEt}_{3}$ & $0.91 \pm 0.00$ & 41 \\
\hline & $\mathrm{Fe}^{\prime}:$ : -S & $0.14 \pm 0.01$ & \\
\hline
\end{tabular}




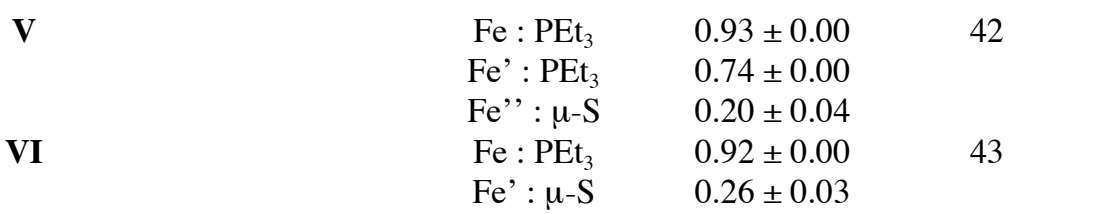

Nomenclature:

$\mathrm{Tp}=$ tris(3-pyrazolyl)borate.

Mes = 2,4,6-trimethylphenyl.

dith = 3,4-dioxocyclobutene-1,2-dithiolate.

HMDS = Hexamethyldisilylamide.

* Contains only one tetracoordinate iron.

Figure S.7
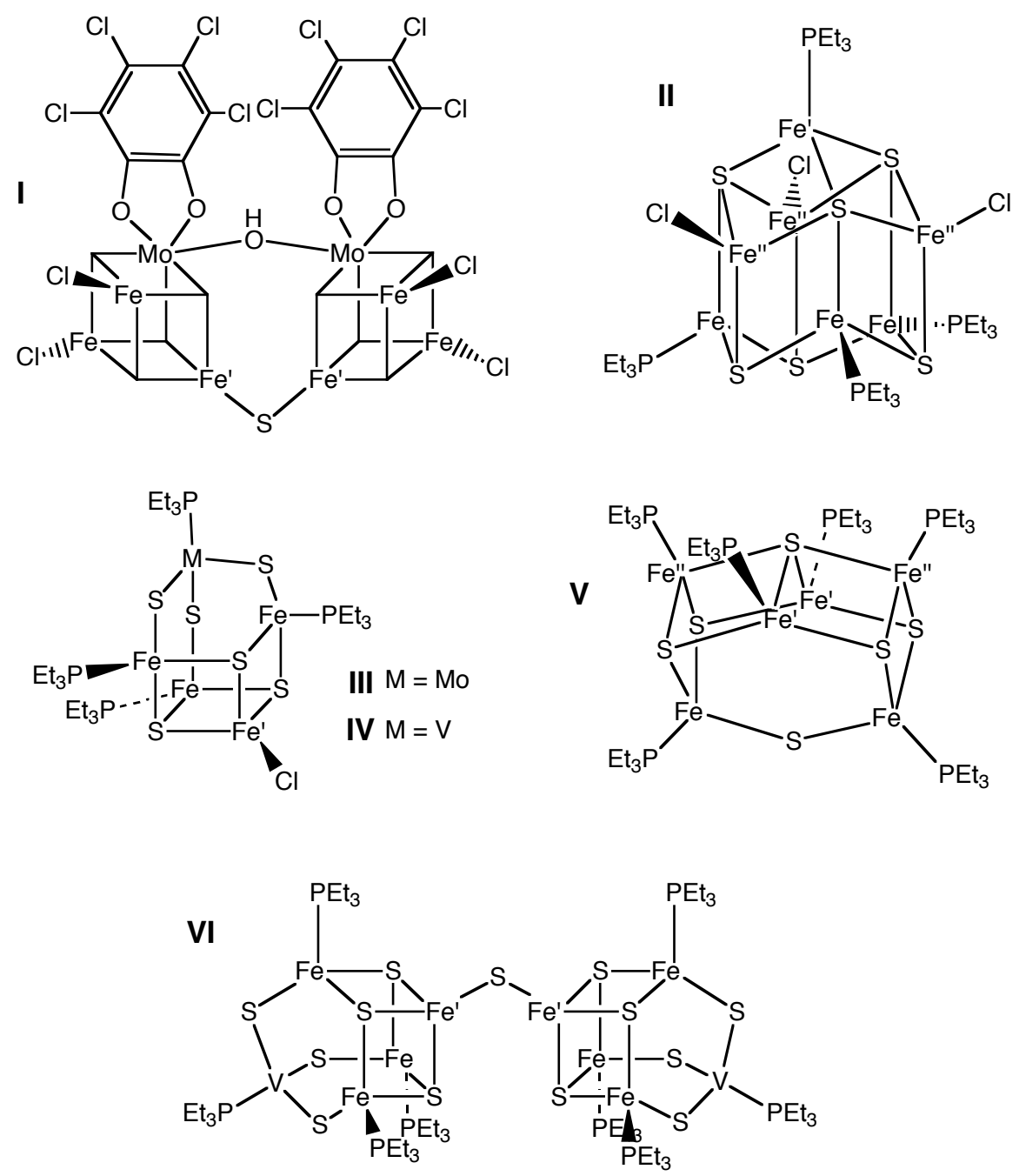


\section{References}

${ }^{1}$ Ming, L.-J. In Physical Methods in Bioinorganic Chemistry, Que, L., Ed.; University Science Books: Sausalito, CA, 2000; pp 375-464. In rapidly tumbling small molecules, $T_{2}$ $\approx T_{1}$.

2 (a) Schubert, E. M. J. Chem. Ed. 1992, 69, 62. (b) Evans, D. F. J. Chem. Soc. 1959, 2003.

${ }^{3}$ Method references: (a) Ngo, T. T.; Phan, A. P. H.; Yam, C. F.; Lenhoff, H. M. Anal. Chem. 1982, 54, 46. (b) Weatherburn, M. W. Anal. Chem. 1967, 39, 971. Recent references using the indophenol method: (c) Yandulov, D. V.; Schrock, R. R. Science 2003, 301, 76. (d) Malinak, S. M.; Demadis, K. D.; Coucouvanis, D. J. Am. Chem. Soc. 1995, 117,3126 .

${ }^{4}$ (a) Smith, J. M.; Lachicotte, R. J.; Holland, P. L. Chem. Commun. 2001, 1542. (b) Vela, J.; Smith, J. M.; Lachicotte, R. J.; Holland, P. L. Chem. Commun. 2002, 2886.

${ }^{5}$ Smith, J. M.; Holland, P. L. Unpublished results.

${ }^{6}$ Connors, K.A. Binding Constants; John Wiley \& Sons: New York, 1987.

${ }^{7}$ Münck, E. "Aspects of ${ }^{57} \mathrm{Fe}$ Mössbauer Spectroscopy," in Physical Methods in Bioinorganic Chemistry (L. Que, Jr., ed.); University Science Books: Sausalito, CA; 2000, pp 287-320.

${ }^{8}$ Smith, J. M.; Lachicotte, R. J.; Holland, P. L. Chem. Commun. 2001, 1542-1543.

${ }^{9}$ Stoian, S.; Smith, J. M.; Holland, P. L.; Bominaar, E. L.; Münck, E., manuscript in preparation.

${ }^{10}$ Andres, H.; Bominaar, E. L. ; Smith, J. M.; Eckert, N. A.; Holland, P. L.; Münck, E. J. Am. Chem. Soc. 2002, 124, 3012.

${ }^{11}$ Maelia, L. E.; Millar, M.; Koch, S. A. Inorg. Chem. 1992, 31, 4594.

${ }^{12}$ Werth, M. T.; Kurtz, D. M.; Howes, B. D.; Huynh, B. H. Inorg. Chem. 1989, 28, 1357.

${ }^{13}$ Beisheng, K.; Jinhua, C. Jiegou Huaxe 1985, 4, 119.

${ }^{14}$ Cooper, L.; Davies, S. C.; Dilworth, J. R.; Hughes, D. L.; Konkol, M.; Richards, R. L.; Sanders, J. R.; Sobota, P. Can. J. Chem. 2001, 79, 490. 
References, continued.

${ }^{15}$ Coucouvanis, D.; Swenson, D.; Baenziger, N. C.; Murphy, C.; Holah, D. G.; Sfarnas, N.; Simopoulos, A.; Kostikas, A. J. Am. Chem. Soc. 1981, 103, 3350.

${ }^{16}$ Millar, J. F.; Lee, J. F.; O’Sullivan, T. O.; Koch, S. A.; Fikar, R. Inorg. Chim. Acta 1996, $243,333$.

${ }^{17}$ Petridis, D.; Terzis, A. Inorg. Chim. Acta 1986, 118, 129.

${ }^{18}$ Evans, P. J. M.; Fitzsimmons, B. W.; Marshall, W. G.; Golder, A. J.; Larkworthy, L. F.; Povey, D. C.; Smith, G. W. J. Chem. Soc., Dalton Trans. 1992, 1065.

${ }^{19}$ Bullen, G. J.; Howlin, B. J.; Silver, J.; Fitzsimmons, B. W.; Sayer, I.; Larkworthy, L. F. J. Chem. Soc. Dalton Trans. 1986, 1937.

${ }^{20}$ Dehnicke, K.; Prinz, H.; Massa, W.; Pebler, J.; Schmidt, R. Z. Anorg. Allg. Chem. 1983, 499, 20.

${ }^{21}$ Jinhua, C.; Jiaxi, L. Jiegou Huaxue 1988, 7, 57.

${ }^{22}$ Henkel, G.; Chen, C. Inorg. Chem. 1993, 32, 1064.

${ }^{23}$ Segal, B. M.; Hoveyda, H. R.; Holm, R. H. Inorg. Chem. 1998, 37, 3440.

${ }^{24}$ Muller, A.; Schladerbeck, N. H.; Bogge, H. Chimia 1985, 39, 24.

${ }^{25}$ Barclay, J. E.; Davies, S. C.; Evans, D. J.; Hughes, D. L.; Longhurst, S. Inorg. Chim. Acta 1999, 291, 101.

${ }^{26}$ Hagen, K. S.; Watson, A. D.; Holm, R. H. Inorg. Chem. 1984, 23, 2984.

${ }^{27}$ Hagen, K. S.; Holm, R. H. Inorg. Chem. 1984, 23, 418.

${ }^{28}$ Berg, J. M.; Hodgson, K. O.; Holm, R. H. J. Am. Chem. Soc. 1979, 101, 4586.

${ }^{29}$ Pohl, S.; Saak, W.; Z. Naturforsch., B: Chem. Sci. 1988, 43, 457.

${ }^{30}$ Carney, M. J.; Papafthymiou, G. C.; Spartalian, K.; Frankel, R. N.; Holm, R. H. J. Am. Chem. Soc. 1988, 110, 6084.

${ }^{31}$ Osterloh, F.; Segal, B. M.; Achim, C.; Holm, R. H. Inorg. Chem. 2000, 39, 980.

${ }^{32}$ Zhang, Y.-P.; Bashkin, J. K.; Holm, R. H. Inorg. Chem. 1987, $26,694$.

${ }^{33}$ Palermo, R. E.; Holm, R. H. J. Am. Chem. Soc. 1983, 105, 4310.

${ }^{34}$ Coucouvanis, D.; Al-Ahmad, S. A.; Salifoglou, A.; Papefthymiou, V.; Kostikas, A.; Simopoulos, A. J. Am. Chem. Soc. 1992, 114, 2472.

${ }^{35}$ Han, J.; Koutmos, M.; Al Ahmad, S.; Coucouvanis, D. Inorg. Chem. 2001, 40, 5985.

${ }^{36}$ Zhang, Y.; Holm, R. H. J. Am. Chem. Soc. 2003, 125, 3910. 
References, continued.

${ }^{37}$ Raebiger, J. W.; Crawford, C. A.; Zhou, J.; Holm, R. H. Inorg. Chem. 1997, 36, 994.

${ }^{38}$ Mascharak, P. K.; Armstrong, W. H.; Mizobe, Y.; Holm, R. H. J. Am. Chem. Soc. 1983, 105,475 .

${ }^{39}$ Coucouvanis, D.; Challen, P. R.; Koo, S.; Davis, W. M.; Butler, W.; Dunham, W. R. Inorg. Chem. 1989, 28, 4181.

${ }^{40}$ Noda, I.; Snyder, B. S.; Holm, R. H. Inorg. Chem. 1986, 25, 3851.

${ }^{41}$ Nordlander, E.; Lee, S. C.; Cen, W.; Wu, Z. Y.; Natoli, C. R.; di Cicco, A.; Filipponi, A.; Hedman, B.; Hodgson, K. O.; Holm, R. H. J. Am. Chem. Soc. 1993, 115, 5549.

${ }^{42}$ Snyder, B. S.; Holm, R. H. Inorg. Chem. 1990, 29, 274.

${ }^{43}$ Huang, J.; Mukerjee, S.; Segal, B. M.; Akashi, H.; Zhou, J.; Holm, R. H. J. Am. Chem. Soc. 1997, 119, 8662. 